\title{
Aflatoxin contamination in food crops: causes, detection, and management: a review
}

\author{
Abhishek Kumar ${ }^{1}$, Hardik Pathak ${ }^{1}$, Seema Bhadauria ${ }^{2}$ and Jebi Sudan ${ }^{1 *}$ (i)
}

\begin{abstract}
Mycotoxins are secondary metabolites produced by several fungal species and molds. Under favorable conditions like high temperature and moisture, they contaminate a large number of food commodities and regional crops during pre and post-harvesting. Aflatoxin is the main mycotoxin that harm animal and human health due to its carcinogenic nature. Aflatoxins are mainly released by Aspergillus flavus and Aspergillus parasiticus. AFB1 constitutes the most harmful type of aflatoxins and is a potent hepato-carcinogenic, mutagenic, teratogenic and it suppresses the immune system. To maintain food safety and to prevent aflatoxin contamination in food crops, combined approaches of using resistant varieties along with recommended farming practices should be followed. This review concentrates on various aspects of mycotoxin contamination in crops and recent methods to prevent or minimize the contamination.
\end{abstract}

Keywords: Mycotoxin, Aflatoxin contamination, Aspergillus flavus, Aspergillus parasiticus, Food crops

\section{Introduction}

Aflatoxin contamination in crops is a global threat that compromises the safety of food, feed, and also influences the agricultural economy and crop-dependent small scale industries. Crops can be contaminated during the process of harvesting, storing, and transporting by the fungi and leads to the productions of several mycotoxins. Mycotoxins are produced by certain fungi as secondary metabolites and aflatoxin is one of them. Aflatoxins are synthesized by many fungi spp. including Aspergillus, Penicillium, Fusarium, and Alternaria but Aspergillus flavus and Aspergillus parasiticus are known to produce the most toxigenic strains of aflatoxins. There are mainly six different types of aflatoxinsAflatoxins-B1 $\left(\mathrm{AFB}_{1}\right), \quad$ Aflatoxins- $\mathrm{B} 2\left(\mathrm{AFB}_{2}\right), \quad$ Aflatoxin G1 $\left(\mathrm{AFG}_{1}\right)$, Aflatoxins $\mathrm{G} 2\left(\mathrm{AFG}_{2}\right)$, Aflatoxin M1 $\left(\mathrm{AFM}_{1}\right)$, and Aflatoxin M2 $\left(\mathrm{AFM}_{2}\right)$ (Quadri et al. 2012). Out of

\footnotetext{
* Correspondence: jebiaksh@gmail.com

'Department of Plant Biotechnology, JECRC University, Jaipur, Rajasthan, India

Full list of author information is available at the end of the article
}

these B1, B2, G1, G2 are found in food crops or their products, while M1 (Metabolite of B1) and M2 are found in the animals' by-products such as dairy products.

Aflatoxin $\mathrm{B} 1$ and $\mathrm{B} 2$ are produced by $A$. flavus, while Aflatoxin G1 and G2 are synthesized by $A$. parasiticus and largely contaminate a wide range of food commodities including cereals (maize, sorghum, pearl millet, rice, and wheat), oilseeds (peanut, soybean, sunflower, and cotton), spices (chilies, black pepper, turmeric, coriander, and ginger), nuts (almond, Brazil nut, pistachio, walnut, and coconut), yam and various milk products (Rajarajan et al. 2013). A. flavus fungus has a green appearance and has the potential to increase its population even under many stressful conditions. The injuries caused by insects and nematode also paved the way for the entry of these fungi (Jeyaramraja et al. 2018). The entry of fungus in crops not only compromises the selfdefense of crop plants by the fungal attack but also contaminates the crop seeds which lead the aflatoxin production. The fungal infections affect the crop's growth, yield, and also result in loss of market value.

(c) The Author(s). 2021 Open Access This article is licensed under a Creative Commons Attribution 4.0 International License, which permits use, sharing, adaptation, distribution and reproduction in any medium or format, as long as you give appropriate credit to the original author(s) and the source, provide a link to the Creative Commons licence, and indicate if changes were made. The images or other third party material in this article are included in the article's Creative Commons licence, unless indicated otherwise in a credit line to the material. If material is not included in the article's Creative Commons licence and your intended use is not permitted by statutory regulation or exceeds the permitted use, you will need to obtain permission directly from the copyright holder. To view a copy of this licence, visit http://creativecommons.org/licenses/by/4.0/. 
Aflatoxin $B_{1}$ is the most harmful aflatoxin to humans and animals as it is carcinogenic due to its association with hepatocellular carcinoma which leads to liver cancer (Qureshi et al. 2015). Aflatoxins suppress the immune systems of humans and animals by interfering with the fickleness of those cells which are responsible to boost immunity. Large doses of aflatoxins lead to direct death and damage, while small longstanding doses lead to immunologic or nutritional effects, but both types of doses lead to liver cancer due to the accumulation of aflatoxin (Marroquín-Cardona et al. 2014). Children are more prone to the toxicity of Aflatoxin as it increases the risk of early infections by reduced immunization. The carcinogenic nature of aflatoxin is due to its ability to damage DNA either by lipid peroxidation or by oxidation (Zhang et al. 2015). The cytochrome $\mathrm{p}-450$ present in the liver activates $A F B_{1}$ which is then converted into $A F B_{1}$ 8,9-epoxide. The compound $\mathrm{AFB}_{1}$ 8,9-epoxide is responsible for various carcinogenic effects (Denissenko et al. 1999). Apart from being carcinogenic, aflatoxin also has negative effects on the kidney, heart, liver, testis, and brain. Aflatoxin was also responsible for the various outbreaks in India and various African countries. The condition of the outbreak is more severe in under-developed and developing countries due to fewer food regulation acts.

To curb the aflatoxins contamination in food crops, countries have imposed different laws regarding the level of these toxins in food crops. The United State Food and Drug Administration (USFDA) imposed strict laws for the aflatoxins level in affected food commodities at $20 \mathrm{ppb}$ (parts per billion) in food and feeds, while $0.5 \mathrm{ppb}$ in milk products European Union (EU) also interpolates the aflatoxin contents level in food commodities in the range of 2-4 ppb (Gurtler \& Keller 2019). In India, a maximum limit of $30 \mu \mathrm{g} / \mathrm{kg}$ has been imposed for all food commodities under the Food Safety and Standards Regulations, 2011. However such laws on Aflatoxins contamination range in various crop plants/food commodities put an extra load of over US\$932 million on the agricultural economy by a reduction in crops growth and yields. Several lakh tones of harvested product go waste every year due to aflatoxin contamination and not fulfilling the export norms.

To minimize the aflatoxins contamination in crop plants, various physical, chemical, and biological methods and various breeding and genetic engineering approach has been used to minimize the toxicity of aflatoxin and reduce its level below the recommended one. This review describes an overview of various aspects of aflatoxigenic fungi, favorable conditions for growth, control measures, detection techniques, and recent reports in various crops.

\section{Favorable conditions for aflatoxin contamination}

Mycotoxins production depends on the food source, enzymes, and various environmental factors. However, the conditions that are favorable for aflatoxigenic fungi are not always conducive for the production of aflatoxins (Mannaa \& Kim 2017). The factors are summarized as:

\section{Physical factors}

Physical factors like $\mathrm{pH}$, light, moisture, temperature, water, relative humidity, and atmospheric gases are responsible for aflatoxin contamination. Aflatoxin-producing molds/Fungi can grow in a wide range of $\mathrm{pH}$ (1.7-9.3), but the optimum range of $\mathrm{pH}$ is (3-7) (Yoshinari et al. 2010). The lower $\mathrm{pH}$ $(3>\mathrm{pH}>1)$ minimizes the fungal growth and a slightly higher $\mathrm{pH}(6>\mathrm{pH}>3)$ promotes both fungal and aflatoxins production (Eshelli et al. 2015). Initial $\mathrm{pH}(\mathrm{pH}=5)$ promote AFB (Aflatoxin B) production while higher $\mathrm{pH}(\mathrm{pH}=7)$ promote AFG (Aflatoxin G) production, however, the composition of media in which fungi grow also influence $\mathrm{pH}$ (Dalié et al. 2010). Fungi growth and aflatoxin production are also affected by the presence of light. Darkness increases aflatoxin production while sunlight inhibits it (Rushing \& Selim 2019). High moisture content always favors the aflatoxin contamination because moist conditions are favorable for fungal growth. Relative humidity (85\%) is optimal for aflatoxins production, while $95 \%$ relative humidity increases aflatoxins production to a considerable level (Ding et al. 2015). However, the water level does not have any reported effect on aflatoxin contamination. Aspergillus flavus poses an excellent survival capability to grow on a wide range of temperatures ranging from $12^{\circ} \mathrm{C}$ to $48^{\circ} \mathrm{C}$, but $28^{\circ} \mathrm{C}$ to $37^{\circ} \mathrm{C}$ is the optimum temperature range for its growth (Hawkins et al. 2005). Aflatoxins production can occur at a wide range of temperature; however, the optimal temperature for aflatoxin production is $25-35^{\circ} \mathrm{C}$ (Siciliano et al. 2017). Normally at high temperatures, AFB production is high than AFG, but at low temperatures both AFB and AFG production is equal (Matumba et al. 2015). Availability of $\mathrm{O}_{2}$ and $\mathrm{CO}_{2}$ also influence the aflatoxins productions. Aflatoxins production and fungal growth are inhibited at a higher level of $\mathrm{CO}_{2}$ and a lower level of $\mathrm{O}_{2}$ (Mahbobinejhad et al. 2019).

\section{Nutritional factors}

Aflatoxin productions are also widely affected by the substrate and various nutritional factors such as carbon, amino acids, nitrogen, lipids, and few trace elements. Substrate rich in carbohydrates supports more production as compare to oil as carbohydrate easily provides carbon which is needed for good fungal growth (Ma et al. 2014). Among carbohydrates glucose, ribose, sucrose, xylose, and glycerol acts as excellent substrates, while peptone, lactose, and sorbose were unable to promote aflatoxins production (Liu et al. 2016). Nitrogen in the form of nitrite and nitrate also increases the aflatoxin production level by $A$. flavus in various ways (Wang, Han, et al. 2017). Lipids also play an important 
role in aflatoxin production. Aflatoxins biosynthesis in toxigenic fungi leads by lipophilic epoxy fatty acids and fungal growth as well as aflatoxin production induced by ergo-sterol oxidation (Reverberi 2014). Consequently, lipids also act as a substrate to obtain an acyl-CoA starter as well as a signaling molecule. The aflatoxin production and accumulation increases in full-fat substrates as compared to the low-fat substrate. The addition of corn oil in defatted wheat, infected by A. flavus promotes aflatoxin production as compare to media without the addition of corn oil (Liu et al. 2016). Vitamins, amino acids, and metal ions also promote aflatoxin production in combination. Amino acids like glycine, glutamate, and alanine along with some bivalent metals like zinc and magnesium promote aflatoxin production (Bolu et al. 2014). The aflatoxin production increased by 4,5 , and 19 times with the 20,50, and $100(\mathrm{mg} / \mathrm{L})$ concentration of zinc respectively (Liu et al., 2016). Amino acid such as tyrosine promotes aflatoxin production, while it is inhibited by tryptophan (Chang et al., 2015). AFB1 production was supported by arginine, glycine, glutamic acid, and aspartic acid at a concentration of $0.5 \%$.

\section{Biological factors}

Biological factors include fungal species, weeds, and insect injuries. Weeds mostly grow as a competitor and cause plant stress which is associated with aflatoxin production. The amount of aflatoxin production mainly depends on types of fungi; insects wound in the plant cause stress and provide the site for aflatoxigenic fungi for contamination (Kinyungu 2019). Aflatoxin production also depends on the types of strains. A. flavus produces fewer aflatoxins as compare to $A$. parasiticus (Manjunath \& Mohana 2018). Apart from the abovementioned factors, A. flavus is the main species that is mainly responsible for aflatoxin production and crop contamination because it is the most copious molds found in soil and possesses the saprobe character that enables it to grow on many organic nutrient substrates including compost piles, plant debris, cotton, dead insects, stored grains, field crops, animal corpses and animal fodder (Kakde 2012). Pre-harvest contaminations of field crops are common because of the natural existence of A. flavus in soil, while post-harvest contamination also occurred by $A$. flavus during storage because it spoils the food grains. Due to the lacking of host specificity A. flavus contaminate both monocot and dicot seeds (Leger et al. 2000).

\section{Aflatoxins contamination in crop plants}

Aflatoxin contamination occurs in a wide range of regional crops and food commodities. Food and feed like corn, rice, spices, dried fruits, nuts, and figs are mostly contaminated by aflatoxins (Martinez-Miranda et al.
2019). The four major aflatoxins like AFB1, AFB2, AFG1, and AFG2 are commonly found in a wide range of food commodities, AFB1 and AFB. 2 are produced by $A$. flavus while AFG1 and AFG2 are produced by $A$. parasiticus. The post-harvest crops are more likely to be contaminated if the storage conditions are optimum for fungus growth. It was found that about $67.9 \%$ of maize samples, $92.9 \%$ of millet samples, and $50 \%$ of sorghum samples that were obtained from a storage room are contaminated by aflatoxins (Sirma et al. 2015). A detailed list of various food crops that were found to be infected with aflatoxin contamination is given in Table 1.

\section{Methods to detect aflatoxin contamination in crop plants}

There are many official methods to detect Aflatoxin contamination in crop plants, which are featured by the Association of Official Analytical Chemists (AOAC) (Kumar et al. 2017). Amongst them, the most commonly used method is Enzyme-Linked Immunosorbent Assay (ELISA) followed by some chromatographic methods including High-Performance Liquid Chromatography (HPLC), Liquid Chromatography-Mass Spectroscopy (LCMS), and Thin Layer Chromatography (TLC) (Sulyok et al. 2015). Wang, Li, et al. 2017 developed a highly specific nanobody-polyclonal antibody sandwich ELISA for detecting both $A$. flavus and $A$. parasiicus with a minimum detection limit of $1 \mu \mathrm{g} / \mathrm{mL}$. Unfortunately, there are some limitations associated with the above-mentioned techniques including their fulsomeness, required high technical skills, and time consumption. Hence, those methods that provide instant results are proved to be useful when considering a large sample. These methods include Polymerase Chain Reaction (PCR), Fluorescence/Near-Infrared Spectroscopy (FS/ NIRS), and Hyper Spectral Imaging (HSI). PCR technique is mainly used for the detection of Aflatoxins producing fungi $A$. flavus at the molecular level (Tao et al. 2018). Consequently, genes detected during molecular screening of $A$. flavus, responsible for Aflatoxin biosynthesis were used as a target gene to find out Aflatoxin by using multiplex PCR. Visible/Near-Infrared technique (VNIR) is also used for the detection of toxin contamination. In many parts of North America, a considerable amount of AFB1 was found on the surface of maize kernels when detected through VNIR (Chu et al. 2017). However, due to the bad image quality of VNIR, some recent studies focused on the combined use of the HSI technique with chemometric data analysis that resulted in better identification of AFB1 on the surface of maize kernels (Kimuli et al. 2018). The advancement in analytical techniques also led to simultaneous detection of aflatoxins with other toxic compounds. Aflatoxins along with zearalenone were simultaneously detected through the use of Time-Resolved Fluorescence Immuno- 
Table 1 List of recent studies showing the mycotoxin contamination in different food crops

\begin{tabular}{|c|c|c|c|c|c|c|}
\hline S. No. & Food crop & Country & Fungus species & Type of Mycotoxin & Mycotoxin concentration (ppb) & References \\
\hline 1. & Corn & Serbia & $\begin{array}{l}\text { A.flavus, } \\
\text { A. parasiticus }\end{array}$ & Total AFs & $1.01-86.10$ & Kos et al. 2013 \\
\hline 2. & Wheat & Saudi Arabia & $\begin{array}{l}\text { A. flavus, } \\
\text { A. parasiticus }\end{array}$ & $\begin{array}{l}\text { AFB1 } \\
\text { AFB2 } \\
\text { AFG1 } \\
\text { AFG2 }\end{array}$ & $\begin{array}{l}2.3 \\
2.6 \\
1.3 \\
0.5\end{array}$ & Al-Wadai et al. 2013 \\
\hline 3. & Maize kernel & Hungary & $\begin{array}{l}\text { A. flavus } \\
\text { A. parasiticus }\end{array}$ & AFB1 & $72.6-73.3$ & Dobolyi et al. 2013 \\
\hline 4. & Red chili & Turkey & $\begin{array}{l}\text { A. flavus, } \\
\text { A. parasiticus }\end{array}$ & $\begin{array}{l}\text { AFB1 } \\
\text { AFB2 } \\
\text { AFG1 }\end{array}$ & $\begin{array}{l}0.24-165 \\
0.15-11.3 \\
0.15-3.88\end{array}$ & Golge et al. 2013 \\
\hline 5. & Groundnut & Ethiopia & $\begin{array}{l}\text { A. flavus, } \\
\text { A. parasiticus }\end{array}$ & Total AFs & $15-11,900$ & Chala et al. 2013 \\
\hline 6. & Fonio millet & Nigeria & A. flavus & $\mathrm{AFB} 1,2$ & $233.2-692.0$ & Ezekiel et al. 2014 \\
\hline 7. & Corn & India & A. flavus & AFB1 & $48-383$ & Mudili et al. 2014 \\
\hline 8. & Sorghum & Ethiopia & A. flavus & $\begin{array}{l}\text { AFB1 } \\
\text { AFB2 }\end{array}$ & $\begin{array}{l}29.5 \\
2.56 \mathrm{ppb}\end{array}$ & Chala et al. 2014 \\
\hline 9. & Rice & Nigeria & A. flavus & AFB1 & 37.26-113.20 ppb & Anthony et al. 2014 \\
\hline 10. & Cashew nuts & Brazil & $\begin{array}{l}\text { A. flavus, } \\
\text { A. parasiticus }\end{array}$ & Total AFs & $0.60-31.50$ & Milhome et al. 2014 \\
\hline 11. & Madidi & Nigeria & $\begin{array}{l}\text { A. flavus } \\
\text { A. parasiticus }\end{array}$ & $\begin{array}{l}\text { AFB1 } \\
\text { AFB2 }\end{array}$ & $\begin{array}{l}0.2-125.60 \\
0.95-18.4\end{array}$ & Anthony et al. 2014 \\
\hline 12. & Rice & China & A. flavus & AFB1 & $0.03-20$ & Lai et al. 2015 \\
\hline \multirow[t]{3}{*}{13.} & Maize & Africa & A. flavus & AFB1 & $0.17-5.3$ & Sirma et al. 2015 \\
\hline & Millet & & & & $0.14-6.4$ & \\
\hline & Sorghum & & & & $0.15-210.1$ & \\
\hline 14. & Guava & Egypt & A. parasiticus & $\begin{array}{l}\text { AFB1 } \\
\text { AFG1 }\end{array}$ & $\begin{array}{l}0.163 \\
0.296\end{array}$ & Embaby \& Hassan 2015 \\
\hline 15. & Dried Fruits & Pakistan & A. flavus & Aflatoxin B1 & $0.04-9.80$ & Masood et al. 2015. \\
\hline 16. & Coffee beans & Spain & A. flavus & $\begin{array}{l}\text { Fumonisins } \\
\text { Total AFs }\end{array}$ & $\begin{array}{l}58.62-537.45 \\
0.25-13.12\end{array}$ & García-Moraleja et al. 2015 \\
\hline 17. & Soybean & Indonesia & A. flavus & $\begin{array}{l}\text { AFB1 } \\
\text { AFB2 } \\
\text { AFG1 } \\
\text { AFG2 }\end{array}$ & $\begin{array}{l}1.50 \\
0.88 \\
0.18 \\
0.43\end{array}$ & Pratiwi et al. 2015 \\
\hline \multirow[t]{4}{*}{18.} & Hazelnut & Italy & A. flavus & AFB1 & 56.00 & Diella et al. 2018 \\
\hline & Almond & & & & 72.00 & \\
\hline & Apricot & & & & 56.3 & \\
\hline & Pistachios & & & & 48.0 & \\
\hline \multirow[t]{2}{*}{19.} & Groundnut & Africa & A. flavus & Aflatoxin B1 & 72.97-195.17 & Magembe et al. 2016 \\
\hline & & & & & 132.7 & Sserumaga et al. 2021 \\
\hline 20. & Peanuts & Zambia & A. flavus & Aflatoxin B1 & $0.015-46.60$ & Bumbangi et al. 2016 \\
\hline 21. & Figs & Turkey & $\begin{array}{l}\text { A. flavus } \\
\text { A. parasiticus } \\
\text { A. niger }\end{array}$ & $\begin{array}{l}\text { AFB1 } \\
\text { AFB2 } \\
\text { AFG1 } \\
\text { AFG2 }\end{array}$ & $\begin{array}{l}0.1-12.5 \\
0.07-0.72 \\
0.08-15.3 \\
0.1-0.38\end{array}$ & Kabak 2016 \\
\hline 22. & Lentil & Turkey & A. flavus & Aflatoxin B1 & $0.57-1.74$ & Baydan et al. 2016 \\
\hline 23. & Rice & Pakistan & A. flavus & Aflatoxin B1 & $0.04-21.30$ & lqbal et al. 2016 \\
\hline 24. & Quince & India & $\begin{array}{l}\text { A. flavus, } \\
\text { A. parasiticus }\end{array}$ & $\begin{array}{l}\text { AFB1 } \\
\text { AFB2 }\end{array}$ & $\begin{array}{l}12.32-241.291 \\
8.231-149.103\end{array}$ & Bala et al. 2016 \\
\hline 25. & Mango seeds & Nigeria & $\begin{array}{l}\text { A. flavus, } \\
\text { A. parasiticus }\end{array}$ & $\begin{array}{l}\text { AFB1 } \\
\text { Total AF }\end{array}$ & $\begin{array}{l}68.1 \\
61.7\end{array}$ & Ezekiel et al. 2016 \\
\hline
\end{tabular}


Table 1 List of recent studies showing the mycotoxin contamination in different food crops (Continued)

\begin{tabular}{|c|c|c|c|c|c|c|}
\hline S. No. & Food crop & Country & Fungus species & Type of Mycotoxin & Mycotoxin concentration (ppb) & References \\
\hline & & & A. parviscleroti & Ochratoxin A & 43.4 & \\
\hline & Melon & & & $\begin{array}{l}\text { AFB1 } \\
\text { Total AF } \\
\text { Ochratoxin A }\end{array}$ & $\begin{array}{l}37.5 \\
48.7 \\
0.6\end{array}$ & \\
\hline 26. & Sunflower & Tanzania & A. flavus & AFB1 & 2.8 & Mmongoyo et al. 2017 \\
\hline 27. & Chilies. & United State (US) & A. flavus & Aflatoxin B1 & $<2$ & Singh \& Cotty 2017 \\
\hline 28. & Sesame & Nigeria & $\begin{array}{l}\text { A. flavus } \\
\text { A. parasiticus } \\
\text { A. niger }\end{array}$ & $\begin{array}{l}\text { AFB1 } \\
\text { AFB2 } \\
\text { AFG1 } \\
\text { AFG2 }\end{array}$ & $\begin{array}{l}3.95-11.75 \\
2.35 \\
2.06 \\
1.47\end{array}$ & Matthew et al. 2021 \\
\hline 29. & Ginger & Nigeria & $\begin{array}{l}\text { A.flavus, } \\
\text { A. parasiticus }\end{array}$ & Total AFs & $0.11-9.52$ & Lippolis et al. 2017. \\
\hline 30. & Corn & Vietnam & A. flavus & Aflatoxin B1 & $1.0-34.80$ & Lee et al. 2017 \\
\hline 31. & Strawberry & Egypt & $\begin{array}{l}\text { A. flavus, } \\
\text { A. parasiticus } \\
\text { A. niger }\end{array}$ & $\begin{array}{l}\text { AFB1 } \\
\text { AFB2 } \\
\text { AFG1 } \\
\text { AFG2 }\end{array}$ & $\begin{array}{l}24.7-51.8 \\
25.8-58.9 \\
33.0-75.2 \\
31.2-71.1\end{array}$ & Saleem 2017 \\
\hline \multirow[t]{6}{*}{32.} & Lentil & India & A. flavus & AFB1 & $3.8-8.6$ & Nazir et al. 2019 \\
\hline & Black pepper & & & AFB1 & $39.7-65.9$ & \\
\hline & Coriander & & & AFB1 & $33.4-67.9$ & \\
\hline & Cumin & & & AFB1 & $24.9-63.9$ & \\
\hline & Aniseed & & & AFB1 & $35.3-52.5$ & \\
\hline & Black gram beans & & & AFB1 & $4.8-15.4$ & \\
\hline 33. & Flax & United States & $\begin{array}{l}\text { A. flavus } \\
\text { A. parasiticus }\end{array}$ & $\begin{array}{l}\text { AFB1 } \\
\text { AFG1 } \\
\text { AFB1 } \\
\text { AFG1 } \\
\text { AFB2 }\end{array}$ & $\begin{array}{l}247 \\
51 \\
324 \\
34 \\
6\end{array}$ & Ting et al. 2020 \\
\hline
\end{tabular}

Chromatographic Assay (TRFICA) (Tang et al. 2017) and anti-idiotypic nanobody-Phage Display-mediated Immune-Polymerase Chain Reaction (PD-IPCR) (Ren et al. 2019). TRFICA and PD-IPCR provides a detection limit of $0.05 \mathrm{ng} / \mathrm{mL}$ and $0.0 .03 \mathrm{ng} / \mathrm{mL}$ respectively for aflatoxins. A recent method also detects aflatoxins and fumonisins (a group of mycotoxins derived from Fusarium spp.) through Color-encoded Lateral Flow ImmunoAssay (CLFIA) (Di Nardo et al. 2019).

Certain nanoparticles-based techniques that use quantum dots (QD), carbon (CBNs), $\mathrm{Au} / \mathrm{Ag}$ are also used to detect different aflatoxins in crop plants (Xue et al. 2019). Furthermore, the use of biosensors for the detection of AFB1 in crop products instead of the chromatographic or spectrophotometric method also gets popularized. The biosensors also permit easy and rapid detection with fewer expenses, minimal sample pretreatment, portability, and on spot identification of aflatoxins by utilizing an electrochemical enzyme-linked oligonucleotide array (Rotariu et al. 2016; Selvolini et al. 2019). Aptamer-based molecular assays are also used for instant detection of aflatoxin in some beverages like wine and certain food crops (Wang et al. 2019).

\section{Measures to control aflatoxin contamination}

Aflatoxin contamination in crops caused a serious threat to production, the food market, health, and economics. Several approaches have been manifested to reduce the aflatoxin contamination in crops which include various physical, chemical, and biological methods.

\section{Physical methods}

Physical methods such as steam under pressure, dry roasting, and other cooking methods are found to be effective in the control or to reduce the aflatoxin contamination in many crops (Peng et al. 2018). About 40-73\% reduction in aflatoxin level was also observed by heating the seed samples on $180^{\circ} \mathrm{C}$ (Opoku 2013). When groundnut and corn seed was roasted with $30 \%$ moisture at $100{ }^{\circ} \mathrm{C}$ temperature for $2 \mathrm{~h}$, there is a reduction of aflatoxin by $85 \%$ (Leong et al. 2010). Roasting also reduced the concentration of AFB1 and AFG1 by 70 and $79 \%$ when the seeds are roasted at $150^{\circ} \mathrm{C}$ for $15 \mathrm{~min}$ (Jalili 2016). An effective reduction in aflatoxin concentration was also observed when the seeds were treated with various radiations such as UV and Infrared radiation (Surekha et al. 2015). 
Sunlight also plays an important role in the detoxification of AFB1 in many crops. A reduction in AFB1 content was found in artificially infected maize (80\%) and groundnut $(17 \%)$ when the seeds are exposed to sunlight for a 10-12 h period (Rushing \& Selim 2019). Consequently, gamma radiation exposure was also found to reduce the aflatoxin level (Aquino 2011). Moisture is a significant factor in fungal growth which leads to the production of aflatoxin in crops. Aflatoxigenic fungi growth and aflatoxin production inhibited by drying groundnut to $6.6 \%$ and maize to $15 \%$ or much lower moisture level within $24-48 \mathrm{~h}$ (Awuah \& Ellis 2002; Eziah, \& \&Afreh-Nuamah, K. 2015). UV irradiation (220-400 nm) also degrades the aflatoxins particularly $\mathrm{AFB}_{1}, \mathrm{AFB}_{2}$, and $\mathrm{AFM}_{1}$ in various crops with a degradation potential ranging from 77 to $99.12 \%$ (Diao et al. 2015).

\section{Chemical methods}

Several chemicals such as acids, alkalis, oxidizing agents, aldehydes, and several gasses are also proved to mitigate the aflatoxigenic fungal growth and aflatoxin production when used in appropriate quantity (Udomkun et al. 2017). Among gasses, ozone was found to be most effective in maximizing the aflatoxin degradation on legumes and cereals by an electrophilic attack on carbon bonds of furan ring (Jalili 2016). However, due to the high-cost factor, ozone treatment is of less use in the post-harvest treatment of crops. Aflatoxin production can also be inhibited by the ammoniation process in corn and other food commodities (Karlovsky et al. 2016). The positive aspect of the ammoniation process is that high-pressure ammoniation $(0.25,0.5,1.5$, and $2 \%)$ minimizes the time required to reduce the aflatoxin production in several crops and food commodities (Temba et al. 2016). Certain chemicals such as sodium bisulfite, calcium hydroxide, formaldehyde, sodium hypochlorite, sodium borate, and sorbents also reduce the aflatoxin in many food commodities at a significant level (Carvajal \& Castillo 2009). The groundnut cake and poultry feed were detoxified from aflatoxin by treating them with sodium bisulfite (0.5\%) and sodium hydroxide (1\%) (Bedi \& Agarwal 2014). Some food additives are also used for the inhibition of fungal growth and aflatoxin production in combination with some physical factors like temperature and moisture. Treatment of citric acid in conjunction with high temperature and pressure leads to the inhibition of fungal growth as well as aflatoxin production in sorghum (Méndez-Albores et al. 2009). Some scientists also observed that some food preservatives such as propionic acid, crystal violet, p-amino benzoic acid, benzoic acid, boric acid, and sodium acetate were also inhibited the A. flavus growth and aflatoxin production (Aiko \& Mehta 2015). In peanut and maize, AFB1 production was also inhibited by the treatment of sodium chloride (10\%), acetic acid (5\%), and propionic acid (5\%) (Brožková et al. 2015). Even under the favorable conditions for the growth of $A$. flavus, several salts of propionic acid-like calcium, sodium propionates were able to reduce the aflatoxin formation in maize (Hassan et al. 2015). In groundnut cake, aflatoxin production by $A$. flavus was also foreclosed by certain week acids such as citric acid, propionic acid, acetic acid, and sorbic acid at several concentrations like 0.25, 0.5, 0.75, and 1\% (Verma et al. 2000). Azole fungicides are also used as a tool to control fungus growth and aflatoxin production with prochloraz being more effective than tebuconazole (Mateo et al. 2017).

\section{Biological methods}

The aflatoxin contamination in agricultural products and many other food commodities are also minimized by the use of various microorganisms. Biological agents such as bacteria, yeasts, molds, and algae exhibit the different potential to degrade the aflatoxin in the emulative environment. Detoxification of aflatoxins by using biological agents is divided into two procedures named absorption and enzymatic decadence (Jard et al. 2011). Aflatoxins can be absorbed by microorganisms directly either by concatenating to their cell wall contents through effectual internalization or congregation (Motawe et al. 2014). Aflatoxins can also be absorbed by dead microorganisms; this ability can be helpful for the fabrication of bio-filters in the form of probiotics and found application in fluid decontamination (Mwakinyali et al. 2019). Degradation of aflatoxins can also be done by intra or extracellular enzymes; the end products of such enzymatic degradation are mostly water and $\mathrm{CO}_{2}$ (Aliabadi et al. 2013). In a study on testing the efficacy of different microbes strains, only Flavobacterium aurantiacum B-184 was found to be effective enough for aflatoxin degradation (Darsanaki \& Miri 2013). However, different bacteria strains were also found to be effective against degrading the $\mathrm{AFB}_{1}$. The cell-free supernatant of strain Bacillus velezensis DY3108 exhibits a strong $\mathrm{AFB}_{1}$ degradation activity of $91.5 \%$ (Shu et al. 2018). The thermophilic bacterial strains (Geobacillus and Tepidimicrobium) also play a major role in $\mathrm{AFB}_{1}$ degradation when used as a microbial consortium (Wang, Zhao, et al. 2017). Moreover, a significant reduction in $A$. flavus growth was observed in pre-harvest crops by inoculation of antagonistic strains of Pseudomonas, Trichoderma, Ralstonia, Lactobacilli, Burkholderia, and Bacillus spp. (Akocak et al. 2015; Yang et al. 2017). Surprisingly aflatoxin contamination was also found to be inhibited by using the non-toxigenic strains of $A$. flavus and other molds as a chief controlling agent (Udomkun et al. 2017). 


\section{Conclusion}

Aflatoxins contamination in food crops and their derived products have become a serious threat to humans and animal's lives. The problem is severe in developing countries where apart from causing a health hazard, the toxin-contaminated products are also losing economic value in the global food market. Various physical, chemical, biological, and nano-particles based approaches are used for minimizing and management of aflatoxin in food crops. However, researchers are also progressing in the development of fungal resistant varieties through breeding and genetic engineering approaches but their outcome is still a major concern. Hence a combined approach of using resistant varieties along with recommended pre-and post-harvest practices should be followed by farmers and food industries to minimize and degrade the aflatoxin content in food crops and their derived products.

\section{Acknowledgments}

Not applicable.

\section{Authors' contributions}

JS conceptualize the idea; AK, JS, and HP write the manuscript; SB edits some part of the manuscript. The authors read and approved the final manuscript.

\section{Funding}

Not received.

\section{Availability of data and materials}

Not applicable.

\section{Declarations}

Ethics approval and consent to participate

Not applicable.

\section{Consent for publication}

Not applicable.

\section{Competing interests}

None.

\section{Author details}

${ }^{1}$ Department of Plant Biotechnology, JECRC University, Jaipur, Rajasthan, India. ${ }^{2}$ Department of Botany, Dr. Bhimrao Ambedkar University, Agra, Uttar Pradesh, India.

Received: 10 July 2020 Accepted: 26 May 2021

Published online: 15 July 2021

\section{References}

Aiko, V., \& Mehta, A. (2015). Occurrence, detection, and detoxification of mycotoxins. Journal of Biosciences, 40(5), 943-954. https://doi.org/10.1007/s12 038-015-9569-6.

Akocak, P. B., Churey, J. J., \& Worobo, R. W. (2015). Antagonistic effect of chitinolytic pseudomonas and bacillus on the growth of fungal hyphae and spores of aflatoxigenic Aspergillus flavus. Food Bioscience, 10, 48-58. https:// doi.org/10.1016/j.fbio.2015.01.005.

Aliabadi, M. A., Alikhani, F. E., Mohammadi, M., \& Darsanaki, R. K. (2013). Biological control of aflatoxins. European Journal of Experimental Biology, 3(2), 162-166.

Al-Wadai, A. S., Al-Othman, M. R., Mahmoud, M. A., \& Abd El-Aziz, A. R. M. (2013) Molecular characterization of Aspergillus flavus and aflatoxin contamination of wheat grains from Saudi Arabia. Genetics and Molecular Research, 12(3), 33353352. https://doi.org/10.4238/2013.September.3.10.
Anthony, M. H., Ojochenemi, A. D., Yemi, A. H. R., Tahir, N., Okechukwu, O. J., Saidu, M. A., \& Ayobami, O. B. (2014). Determination of aflatoxins in sesame, rice, millet, and acha from Nigeria using HPLC. Chemical Science Transactions, 3(4), 1516-1524.

Aquino, S. (2011). Gamma radiation against toxigenic fungi in food, medicinal, and aromatic herbs. In A. Mendez-Vilas (Ed.), Science against microbial pathogens: Communicating current research and technological advances, (pp. 272-281).

Awuah, R. T., \& Ellis, W. O. (2002). Effects of some groundnut packaging methods and protection with Ocimum and Syzygium powders on kernel infection by fungi. Mycopathologia, 154(1), 29-36. https://doi.org/10.1023/A:1015259518448.

Bala, P., Gupta, D., \& Sharma, Y. P. (2016). Mycoflora and natural aflatoxin contamination in dried quince seeds from Jammu, India. Journal of Environmental Biology, 37(1), 101-106.

Baydan, E., Küçükersan, S., Yurdakök, D. B., Aydin, F. G., Sevin, S., Arslanbaş, E., \& Cetinkaya, M. A. (2016). Comparison of nutritional composition (moisture, ash, crude protein, nitrogen) and safety (aflatoxin, nitrate/nitrite) of organic and conventional rice and lentil samples consumed in Ankara. Ankara Üniversitesi Veteriner Fakültesi Dergisi, 63(4), 365-370.

Bedi, P. S., \& Agarwal, R. K. (2014). Detoxification of aflatoxin B1 by physical and chemical methods. World Journal of Pharmacy and Pharmaceutical Sciences, 3(12), 995-1002.

Bolu, S. A., Elelu, N., Ahmed, R. N., Solaojo, F. E., Daramola, K. F., Omotosho, V. S., Afeni, M. (2014). Effect of vitamins, amino acids, and Phyto-active biomolecules on Aspergillus flavus in poultry production. Pharmacology and Therapeutics, 21-58.

Brožková, I., Šmahová, P., Vytřasová, J., Motkková, P., Pejchalová, M., \& Šilha, D. (2015). Influence of chosen microbes and some chemical substances on the production of aflatoxins. Potravinarstvo Slovak Journal of Food Sciences, 9(1), 9-17.

Bumbangi, N. F., Muma, J. B., Choongo, K., Mukanga, M., Velu, M. R., Veldman, F., \& Mapatano, M. A. (2016). Occurrence and factors associated with aflatoxin contamination of raw peanuts from Lusaka district's markets, Zambia. Food Control, 68, 291-296. https://doi.org/10.1016/j.foodcont.2016.04.004.

Carvajal, M., \& Castillo, P. (2009). Effects of aflatoxins contaminating food on human health. Tropical Biology and Conservation Management, 7, 60-84.

Chala, A., Mohammed, A., Ayalew, A., \& Skinnes, H. (2013). Natural occurrence of aflatoxins in groundnut (Arachis hypogaea L.) from eastern Ethiopia. Food Control, 30(2), 602-605. https://doi.org/10.1016/j.foodcont.2012.08.023.

Chala, A., Taye, W., Ayalew, A., Krska, R., Sulyok, M., \& Logrieco, A. (2014). Multi mycotoxin analysis of sorghum (Sorghum bicolor L. Moench) and finger millet (Eleusine coracana L. Garten) from Ethiopia. Food Control, 45, 29-35. https://doi.org/10.1016/j.foodcont.2014.04.018.

Chang, P. K., Hua, S. S. T., Sarreal, S. B. L., \& Li, R. W. (2015). Suppression of aflatoxin biosynthesis in Aspergillus flavus by 2-phenyl ethanol is associated with stimulated growth and decreased degradation of branched-chain amino acids. Toxins, 7(10), 3887-3902. https://doi.org/10.3390/toxins7103887.

Chu, X., Wang, W., Yoon, S. C., Ni, X., \& Heitschmidt, G. W. (2017). Detection of aflatoxin B1 (AFB1) in individual maize kernels using short wave infrared (SWIR) hyperspectral imaging. Biosystems Engineering, 157, 13-23. https://doi. org/10.1016/j.biosystemseng.2017.02.005

Dalié, D. K. D., Deschamps, A. M., \& Richard-Forget, F. (2010). Lactic acid bacteriapotential for control of mold growth and mycotoxins: A review. Food Control 21(4), 370-380. https://doi.org/10.1016/j.foodcont.2009.07.011.

Darsanaki, R., \& Miri, M. (2013). Aflatoxin M1 contamination in dairy products. Journal of Science and today's World, 2, 500-514.

Denissenko, M. F., Cahill, J., Koudriakova, T. B., Gerber, N., \& Pfeifer, G. P. (1999). Quantitation and mapping of aflatoxin B1-induced DNA damage in genomic DNA using aflatoxin B1-8, 9-epoxide, and microsomal activation systems. Mutation Research, Fundamental and Molecular Mechanisms of Mutagenesis, 425(2), 205-211. https://doi.org/10.1016/S0027-5107(99)00038-X.

Di Nardo, F., Alladio, E., Baggiani, C., Cavalera, S., Giovannoli, C., Spano, G., \& Anfossi, L. (2019). Color-encoded lateral flow immunoassay for the simultaneous detection of aflatoxin B1 and type-B fumonisins in a single test line. Talanta, 192, 288-294. https://doi.org/10.1016/j.talanta.2018.09.037.

Diao, E., Li, X., Zhang, Z., Ma, W., Ji, N., \& Dong, H. (2015). Ultraviolet irradiation detoxification of aflatoxins. Trends in Food Science \& Technology, 42(1), 64-69. https://doi.org/10.1016/j.tifs.2014.12.001.

Diella, G., Caggiano, G., Ferrieri, F., Ventrella, A., Palma, M., Napoli, C., Rutigliano, S., Lopuzzo, M., Lovero, G. and Montagna, M.T. (2018). Aflatoxin contamination in nuts marketed in Italy: preliminary results. Ann Ig, 30(5), 401-9.

Ding, N., Xing, F., Liu, X., Selvaraj, J. N., Wang, L., Zhao, Y., ... Liu, Y. (2015). Variation in the fungal microbiome (mycobiome) and aflatoxin in stored in-shell peanuts at four different areas of China. Frontiers in Microbiology, 6, 1055. 
Dobolyi, C. S., Sebők, F., Varga, J., Kocsubé, S., Szigeti, G., Baranyi, N., \& Szoboszlay, S. (2013). The occurrence of aflatoxin producing Aspergillus flavus isolates in maize kernel in Hungary. ActaAlimentaria, 42(3), 451-459.

Embaby, E., \& Hassan, M. K. (2015). The decay of guava fruit (Psidium quajava Linn.) quality caused by some mold fungi. International Journal of Agricultural Technology, 11(3), 713-730.

Eshelli, M., Harvey, L., Edrada-Ebel, R., \& McNeil, B. (2015). Metabolomics of the bio-degradation process of aflatoxin $\mathrm{B} 1$ by actinomycetes at an initial $\mathrm{pH}$ of 6.0. Toxins, 7(2), 439-456. https://doi.org/10.3390/toxins7020439.

Ezekiel, C. N., Sulyok, M., Somorin, Y., Odutayo, F. I., Nwabekee, S. U., Balogun, A. T. , \& Krska, R. (2016). Mould and mycotoxin exposure assessment of melon and bush mango seeds, two common soup thickeners consumed in Nigeria. International Journal of Food Microbiology, 237, 83-91. https://doi.org/10.101 6/j.ijfoodmicro.2016.08.019.

Ezekiel, C. N., Udom, I. E., Frisvad, J. C., Adetunji, M. C., Houbraken, J., Fapohunda, S. O., ... Onashile, O. A. (2014). Assessment of aflatoxigenic Aspergillus flavus and other fungi in millet and sesame from plateau state, Nigeria. Mycology, $5(1), 16-22$

Eziah, V. Y., \&Afreh-Nuamah, K. (2015). Traditional storage practices on the quality of maize a case study in the ShaiOsudoku District in the Greater Accra region. Doctoral dissertation, University of Ghana.

García-Moraleja, A., Font, G., Mañes, J., \& Ferrer, E. (2015). Analysis of mycotoxins in coffee and risk assessment in Spanish adolescents and adults. Food and Chemical Toxicology, 86, 225-233. https://doi.org/10.1016/j.fct.2015.10.014.

Golge, O., Hepsag, F., \& Kabak, B. (2013). Incidence and level of aflatoxin contamination in chili commercialized in Turkey. Food Control, 33(2), 514520. https://doi.org/10.1016/j.foodcont.2013.03.048.

Gurtler, J. B., \& Keller, S. E. (2019). Microbiological safety of dried spices. Annual Review of Food Science and Technology, 10(1), 409-427. https://doi.org/10.114 6/annurev-food-030216-030000.

Hassan, R., El-Kadi, S., \& Sand, M. (2015). Effect of some organic acids on some fungal growth and the production of their toxins. International Journal of Advances in Biology, 2(1), 1-11.

Hawkins, L. K., Windham, G. L., \& Williams, W. P. (2005). Effect of different postharvest drying temperatures on Aspergillus flavus survival and aflatoxin content in five maize hybrids. Journal of Food Protection, 68(7), 1521-1524. https://doi.org/10.4315/0362-028X-68.7.1521.

Iqbal, S. Z., Asi, M. R., Hanif, U., Zuber, M., \& Jinap, S. (2016). The presence of aflatoxins and ochratoxin a in rice and rice products; and evaluation of dietary intake. Food Chemistry, 210, 135-140. https://doi.org/10.1016/j. foodchem.2016.04.104.

Jalili, M. (2016). A review of aflatoxins reduction in food. Iranian Journal of Health, Safety, and Environment, 3(1), 445-459.

Jard, G., Liboz, T., Mathieu, F., Guyonvarc'h, A., \& Lebrihi, A. (2011). Review of mycotoxin reduction in food and feed: From prevention in the field to detoxification by adsorption or transformation. Food Additives \& Contaminants: Part A, 28(11), 1590-1609. https://doi.org/10.1080/19440049.2 011.595377.

Jeyaramraja, P. R., Meenakshi, S. N., \& Woldesenbet, F. (2018). Relationship between drought and preharvest aflatoxin contamination in groundnut (Arachis hypogaea L.). World Mycotoxin Journal, 11(2), 187-199. https://doi. org/10.3920/WMJ2017.2248.

Kabak, B. (2016). Aflatoxins in hazelnuts and dried figs: Occurrence and exposure assessment. Food Chemistry, 211, 8-16. https://doi.org/10.1016/j.foodchem.2 016.04.141.

Kakde, U. B. (2012). Fungal bioaerosols: Global diversity, distribution, and its impact on human beings and crops. Bionano Genmics, 5, 323-329.

Karlovsky, P., Suman, M., Berthiller, F., De Meester, J., Eisenbrand, G., Perrin, I., \& Dussort, P. (2016). Impact of food processing and detoxification treatments on mycotoxin contamination. Mycotoxin Research, 32(4), 179-205. https://doi. org/10.1007/s12550-016-0257-7.

Kimuli, D., Wang, W., Lawrence, K. C., Yoon, S. C., Ni, X., \& Heitschmidt, G. W. (2018). The utilization of visible/near-infrared hyperspectral images to classify aflatoxin B1 contaminated maize kernels. Biosystems Engineering, 166, 150160. https://doi.org/10.1016/j.biosystemseng.2017.11.018.

Kinyungu, S. W. (2019). Efficacy of pre-harvest Aspergillus flavus biocontrol treatment on reducing aflatoxin accumulation during drying. Doctoral dissertation, Purdue University Graduate School.

Kos, J., Mastilović, J., Hajnal, E. J., \& Šarić, B. (2013). Natural occurrence of aflatoxins in maize harvested in Serbia during 2009-2012. Food Control, 34(1), 31-34. https://doi.org/10.1016/j.foodcont.2013.04.004.
Kumar, P., Mahato, D. K., Kamle, M., Mohanta, T. K., \& Kang, S. G. (2017). Aflatoxins: A global concern for food safety, human health, and their management. Frontiers in Microbiology, 7, 2170.

Lai, X., Liu, R., Ruan, C., Zhang, H., \& Liu, C. (2015). The occurrence of aflatoxins and ochratoxin a in rice samples from six provinces in China. Food Control, 50, 401-404. https://doi.org/10.1016/j.foodcont.2014.09.029.

Lee, H. S., Nguyen-Viet, H., Lindahl, J., Thanh, H. M., Khanh, T. N., Hien, L. T. T., \& Grace, D. (2017). A survey of aflatoxin B1 in maize and awareness of aflatoxins in Vietnam. World Mycotoxin Journal, 10(2), 195-202. https://doi. org/10.3920/WMJ2016.2144.

Leger, R. J. S., Screen, S. E., \& Shams-Pirzadeh, B. (2000). Lack of host specialization in Aspergillus flavus. Applied and Environmental Microbiology, 66(1), 320-324. https://doi.org/10.1128/AEM.66.1.320-324.2000.

Leong, Y. H., Ismail, N., Latif, A. A., \& Ahmad, R. (2010). Aflatoxin occurrence in nuts and commercial nutty products in Malaysia. Food Control, 21(3), 334338. https://doi.org/10.1016/j.foodcont.2009.06.002.

Lippolis, V., Irurhe, O., Porricelli, A. C. R., Cortese, M., Schena, R., Imafidon, T., \& Pascale, M. (2017). Natural co-occurrence of aflatoxins and ochratoxin a in ginger (Zingiber officinale) from Nigeria. Food Control, 73, 1061-1067. https:// doi.org/10.1016/j.foodcont.2016.10.026.

Liu, J., Sun, L., Zhang, N., Zhang, J., Guo, J., Li, C., \& Qi, D. (2016). Effects of nutrients in substrates of different grains on aflatoxin B1 production by Aspergillus flavus. BioMed Research International.

Ma, X., Wang, W., Chen, X., Xia, Y., Wu, S., Duan, N. and Wang, Z., 2014. Selection, identification, and application of Aflatoxin B1 aptamer. European Food Research and Technology, 238(6), 919-925.

Magembe, K. S., Mwatawala, M. W., Mamiro, D. P., \& Chingonikaya, E. E. (2016). Assessment of awareness of mycotoxins infections in stored maize (Zea mays L.) and groundnut (Arachis hypogea L.) in Kilosa District, Tanzania. International Journal of Food Contamination, 3(1), 12.

Mahbobinejhad, Z., Aminian, H., Ebrahimi, L., \& Vahdati, K. (2019). Reduction of aflatoxin production by exposing Aspergillus flavus to CO2. Journal of Crop Protection, 8(4), 441-448.

Manjunath, K., \& Mohana, D. C. (2018). Assessment of contamination levels and characterization of Aflatoxin B1 producing Aspergillusflavus strain from food and feed samples from local markets of South India. International Journal of Life Sciences, 6(1), 326-334.

Mannaa, M., \& Kim, K. D. (2017). Influence of temperature and water activity on deleterious fungi and mycotoxin production during grain storage. Mycobiology, 45(4), 240-254. https://doi.org/10.5941/MYCO.2017.45.4.240.

Marroquín-Cardona, A. G., Johnson, N. M., Phillips, T. D., \& Hayes, A. W. (2014). Mycotoxins in a changing global environment-a review. Food and Chemical Toxicology, 69, 220-230. https://doi.org/10.1016/j.fct.2014.04.025.

Martinez-Miranda, M. M., Rosero-Moreano, M., \& Taborda-Ocampo, G. (2019). Occurrence, dietary exposure, and risk assessment of aflatoxins in the arepa, bread, and rice. Food Control, 98, 359-366. https://doi.org/10.1016/j. foodcont.2018.11.046.

Masood, M., Iqbal, S. Z., Asi, M. R., \& Malik, N. (2015). Natural occurrence of aflatoxins in dry fruits and edible nuts. Food Control, 55, 62-65. https://doi. org/10.1016/j.foodcont.2015.02.041.

Mateo, E. M., Gómez, J. V., Gimeno-Adelantado, J. V., Romera, D., Mateo-Castro, R., \& Jiménez, M. (2017). Assessment of azole fungicides as a tool to control growth of Aspergillus flavus and aflatoxin B1 and B2 production in maize. Food Additives \& Contaminants: Part A, 34(6), 1039-1051. https://doi.org/10.1 080/19440049.2017.1310400.

Matthew, E., Oluma, H.O.A., Ochokwunu, D.I., Eche, C.O. and Olasan, J.O. (2021). Aflatoxin Contamination Levels in Sesame Seeds Sold in Benue State, North Central Nigeria. American Journal of Food Science and Health, 7(1),14-23.

Matumba, L., Sulyok, M., Njoroge, S. M., Ediage, E. N., Van Poucke, C., De Saeger, S. , \& Krska, R. (2015). Uncommon occurrence ratios of aflatoxin B 1, B 2, G 1, and $\mathrm{G} 2$ in maize and groundnuts from Malawi. Mycotoxin Research, 37(1), 57-62. https://doi.org/10.1007/s12550-014-0209-z.

Méndez-Albores, A., Veles-Medina, J., Urbina-Álvarez, E., Martínez-Bustos, F., \& Moreno-Martínez, E. (2009). Effect of citric acid on aflatoxin degradation and on functional and textural properties of extruded sorghum. Animal Feed Science and Technology, 150(3-4), 316-329. https://doi.org/10.1016/j.a nifeedsci.2008.10.007.

Milhome, M. A. L., Lima, C. G., De Lima, L. K., Lima, F. A. F., Sousa, D. O. B., \& Nascimento, R. F. (2014). Occurrence of aflatoxins in cashew nuts produced in northeastern Brazil. Food Control, 42, 34-37. https://doi.org/10.1016/j. foodcont.2014.01.033. 
Mmongoyo, J. A., Wu, F., Linz, J. E., Nair, M. G., Mugula, J. K., Tempelman, R. J., \& Strasburg, G. M. (2017). Aflatoxin levels in sunflower seeds and cakes collected from micro-and small-scale sunflower oil processors in Tanzania. PLoS One, 12(4), e0175801. https://doi.org/10.1371/journal.pone.0175801.

Motawe, H. F. A., Salam, A. A., \& El-Meleigy, K. M. (2014). Reducing the toxicity of aflatoxin in broiler chickens' diet by using probiotics and yeast. International Journal of Poultry Science, 13(7), 397-407. https://doi.org/10.3923/ijps.2014.397.407.

Mudili, V., Siddaih, C. N., Nagesh, M., Garapati, P., Naveen Kumar, K., Murali, H. S., \& Batra, H. V. (2014). Mold incidence and mycotoxin contamination in freshly harvested maize kernels originated from India. Journal of the Science of Food and Agriculture, 94(13), 2674-2683. https://doi.org/10.1002/jsfa.6608.

Mwakinyali, S. E., Ding, X., Ming, Z., Tong, W., Zhang, Q., \& Li, P. (2019). The recent development of aflatoxin contamination biocontrol in agricultural products. Biological Control, 128, 31-39. https://doi.org/10.1016/j.biocontrol.2018.09.012.

Nazir, A., Kalim, I., Sajjad, M., Usman, M., \& Iqbal, M. (2019). Prevalence of aflatoxin contamination in pulses and spices in different regions of Punjab. Chemical International, 5(4), 274-280.

Opoku, G. F. (2013). Process and product optimization and storage characteristics of canned Peanut Soup Base. Doctoral dissertation, University of Ghana.

Peng, W. X., Marchal, J. L. M., \& Van der Poel, A. F. B. (2018). Strategies to prevent and reduce mycotoxins for compound feed manufacturing. Animal Feed Science and Technology, 237, 129-153. https://doi.org/10.1016/j.anifeedsci.2018.01.017.

Pratiwi, C., Rahayu, W. P., Lioe, H. N., Herawati, D., Broto, W., \& Ambarwati, S. (2015). The effect of temperature and relative humidity for Aspergillus flavus $\mathrm{BIO} 2237$ growth and aflatoxin production on soybeans. International Food Research Journal, 22(1), 82

Quadri, S. H., Ms, N., Kc, C., Shantaram, U., \& Hs, E. (2012). An overview of chemistry, toxicity, analysis, and control of aflatoxins. International Journal of Chemical and Life Sciences, 2, 1071-1078.

Qureshi, H., Hamid, S. S., Ali, S. S., Anwar, J., Siddiqui, A. A., \& Khan, N. A. (2015). Cytotoxic effects of aflatoxin B1 on human brain microvascular endothelial cells of the blood-brain barrier. Medical Mycology, 53(4), 409-416. https://doi. org/10.1093/mmy/myv010.

Rajarajan, P. N., Rajasekaran, K. M., \& Devi, N. K. (2013). Aflatoxin contamination in agricultural commodities. Indian Journal of Pharmaceutical and Biological Research, 1(4), 148-151. https://doi.org/10.30750/ijpbr.1.4.25.

Ren, X., Zhang, Q., Wu, W., Yan, T., Tang, X., Zhang, W., \& Li, P. (2019). Antiidiotypic nanobody-phage display-mediated real-time immuno-PCR for sensitive, simultaneous, and quantitative detection of total aflatoxins and zearalenone in grains. Food Chemistry, 297, 124912. https://doi.org/10.1016/j. foodchem.2019.05.186.

Reverberi, M. (2014). Lipids in Aspergillus flavus-maize interaction. Frontiers in Microbiology, 5, 74.

Rotariu, L., Lagarde, F., Jaffrezic-Renault, N., \& Bala, C. (2016). Electrochemical biosensors for fast detection of food contaminants-trends and perspective. TrAC Trends in Analytical Chemistry, 79, 80-87. https://doi.org/10.1016/j.trac.2015.12.017.

Rushing, B. R., \& Selim, M. I. (2019). Aflatoxin B1: A review on metabolism, toxicity, occurrence in food, occupational exposure, and detoxification methods. Food and Chemical Toxicology, 124, 81-100. https://doi.org/10.1016/j.fct.2018.11.047.

Saleem, A. R. (2017). Mycobiota and molecular detection of Aspergillus flavus and A. parasiticus aflatoxin contamination of strawberry (Fragaria ananassa Duch. ) fruits. Archives of Phytopathology and Plant Protection, 50(19-20), 982-996. https://doi.org/10.1080/03235408.2017.1411155.

Selvolini, G., Lettieri, M., Tassoni, L., Gastaldello, S., Grillo, M., Maran, C., \& Marrazza, G. (2019). Electrochemical enzyme-linked oligonucleotide array for aflatoxin B1 detection. Talanta, 203, 49-57. https://doi.org/10.1016/j.talanta.2019.05.044.

Shu, X., Wang, Y., Zhou, Q., Li, M., Hu, H., Ma, Y., \& Wu, L. (2018). Biological degradation of aflatoxin B1 by cell-free extracts of bacillus velezensis DY3108 with broad PH stability and excellent thermostability. Toxins, 10(8), 330. https://doi.org/10.3390/toxins10080330.

Siciliano, I., Berta, F., Bosio, P., Gullino, M. L., \& Garibaldi, A. (2017). Effect of different temperatures and $\mathrm{CO} 2$ levels on Alternaria toxins produced on the cultivated rocket, cabbage, and cauliflower. World Mycotoxin Journal, 10(1), 63-71. https://doi.org/10.3920/WMJ2016.2108.

Singh, P., \& Cotty, P. J. (2017). Aflatoxin contamination of dried red chilies: Contrasts between the United States and Nigeria, two markets differing in regulation enforcement. Food Control, 80, 374-379. https://doi.org/10.1016/j. foodcont.2017.05.014.

Sirma, A. J., Ouko, E. O., Murithi, G., Mburugu, C., Mapenay, I., Ombui, J. N., \& Korhonen, H. (2015). Prevalence of aflatoxin contamination in cereals from Nandi County, Kenya. International Journal of Agricultural Sciences and Veterinary, 3, 3.
Sserumaga, J. P., Wagacha, J. M., Biruma, M., \& Mutegi, C. K. (2021). Contamination of groundnut (Arachis hypogaea L.) with Aspergillus section Flavi communities and aflatoxin at the post-harvest stage. Food Control, 128,1-8.

Sulyok, M., Beed, F., Boni, S., Abass, A., Mukunzi, A., \& Krska, R. (2015). Quantitation of multiple mycotoxins and cyanogenic glucosides in cassava samples from Tanzania and Rwanda by an LC-MS/MS-based multi-toxin method. Food Additives \& Contaminants: Part A, 32(4), 488-502. https://doi.org/10.1080/1944 0049.2014.975752.

Surekha, M., Reddy, V. K., \& Reddy, S. M. (2015). 15 eco-friendly Management of Mycotoxigenic Fungi and Mycotoxin Contamination. Sustainable Crop Disease Management using Natural Products, 265. https://doi.org/10.1079/9781 780643236.0265.

Tang, X., Li, P., Zhang, Q., Zhang, Z., Zhang, W., \& Jiang, J. (2017). Time-resolved fluorescence immunochromatographic assay developed using two idiotypic nanobodies for rapid, quantitative, and simultaneous detection of aflatoxin and zearalenone in maize and its products. Analytical Chemistry, 89(21), 11520-11528. https://doi.org/10.1021/acs.analchem.7b02794.

Tao, F., Yao, H., Hruska, Z., Burger, L. W., Rajasekaran, K., \& Bhatnagar, D. (2018). The recent development of optical methods in rapid and non-destructive detection of aflatoxin and fungal contamination in agricultural products. TrAC Trends in Analytical Chemistry, 100, 65-81. https://doi.org/10.1016/j.trac.2 017.12.017.

Temba, B. A., Sultanbawa, Y., Kriticos, D. J., Fox, G. P., Harvey, J. J., \& Fletcher, M. T. (2016). Tools for defusing a major global food and feed safety risk: Nonbiological postharvest procedures to decontaminate mycotoxins in foods and feeds. Journal of Agricultural and Food Chemistry, 64(47), 8959_ 8972. https://doi.org/10.1021/acs.jafc.6b03777.

Ting, W. E., Chang, C. H., Szonyi, B., \& Gizachew, D. (2020). Growth and Aflatoxin B1, B2, G1, and G2 production by Aspergillus flavus and Aspergillus parasiticus on ground flax seeds (Linum usitatissimum). Journal of Food Protection, 83(6), 975-983. https://doi.org/10.4315/JFP-19-539.

Udomkun, P., Wiredu, A. N., Nagle, M., Müller, J., Vanlauwe, B., \& Bandyopadhyay, R. (2017). Innovative technologies to manage aflatoxins in foods and feeds and the profitability of application-a review. Food Control, 76, 127-138. https://doi.org/10.1016/j.foodcont.2017.01.008.

Verma, R. K., Bedi, P. S., \& Agarwal, R. K. (2000). Inhibitive effect of organic acids on aflatoxin production in groundnut cake. Indian Journal of Toxicology, 7(2), 117-119.

Wang, B., Han, X., Bai, Y., Lin, Z., Qiu, M., Nie, X., \& Wang, S. (2017). Effects of nitrogen metabolism on growth and aflatoxin biosynthesis in Aspergillus flavus. Journal of Hazardous Materials, 324(Pt B), 691-700. https://doi.org/10.1 016/j.jhazmat.2016.11.043.

Wang, C., Sun, L., \& Zhao, Q. (2019). A simple aptamer molecular beacon assay for rapid detection of aflatoxin B1. Chinese Chemical Letters, 30(5), 1017-1020. https://doi.org/10.1016/j.cclet.2019.01.029.

Wang, T., Li, P., Zhang, Q., Zhang, W., Zhang, Z., Wang, T., \& He, T. (2017). Determination of Aspergillus pathogens in agricultural products by a specific nanobody-polyclonal antibody sandwich ELISA. Scientific Reports, 7(1), 1-11.

Wang, Y., Zhao, C., Zhang, D., Zhao, M., Zheng, D., Lyu, Y., ... Cui, Z. (2017). Effective degradation of aflatoxin B1 using a novel thermophilic microbial consortium TADC7. Bioresource Technology, 224, 166-173. https://doi.org/10.1 016/j.biortech.2016.11.033.

Xue, Z., Zhang, Y., Yu, W., Zhang, J., Wang, J., Wan, F., \& Kou, X. (2019). Recent advances in aflatoxin $B 1$ detection based on nanotechnology and nanomaterials-a review. Analytica Chimica Acta, 1069, 1-27. https://doi.org/10.1016/j.aca.2019.04.032.

Yang, X., Zhang, Q., Chen, Z. Y., Liu, H., \& Li, P. (2017). Investigation of Pseudomonas fluorescens strain 3JW1 on preventing and reducing aflatoxin contaminations in peanuts. PLoS One, 12(6), e0178810. https://doi.org/10.13 71/journal.pone.0178810.

Yoshinari, T., Noda, Y., Yoda, K., Sezaki, H., Nagasawa, H., \& Sakuda, S. (2010). Inhibitory activity of blasticidin $\mathrm{a}$, a strong aflatoxin production inhibitor, on protein synthesis of yeast: Selective inhibition of aflatoxin production by protein synthesis inhibitors. The Journal of Antibiotics, 63(6), 309-314. https://doi.org/10.1038/ja.2010.36.

Zhang, J., Zheng, N., Liu, F., Li, S., Li, \& Wang, J. I. (2015). Aflatoxin B1 and aflatoxin $\mathrm{M} 1$ induced cytotoxicity and DNA damage in differentiated and undifferentiated Caco-2 cells. Food and Chemical Toxicology, 83, 54-60. https://doi.org/10.1016/j.fct.2015.05.020.

\section{Publisher's Note}

Springer Nature remains neutral with regard to jurisdictional claims in published maps and institutional affiliations. 